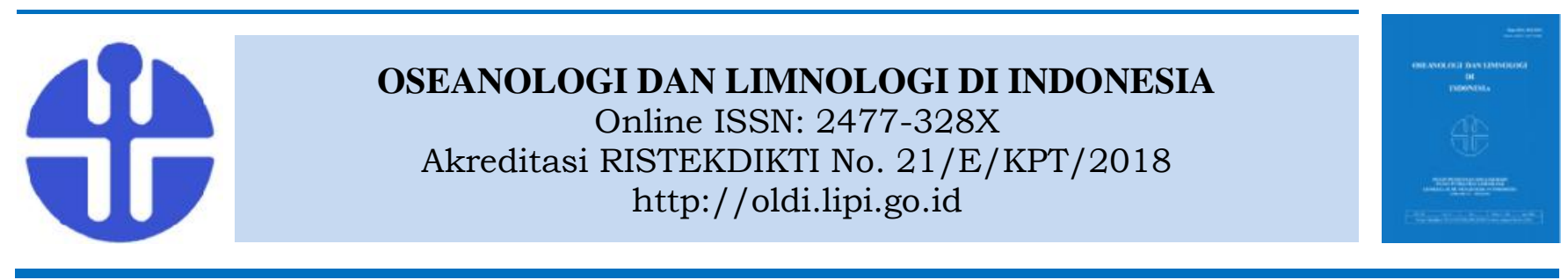

\title{
Evaluasi Rehabilitasi Riparian Sungai Ranggeh dengan Menggunakan Indikator Komunitas Makrozoobenthos
}

\author{
Jojok Sudarso ${ }^{1}$, Imroatushshoolikhah ${ }^{1}$, Aiman Ibrahim ${ }^{1}$, Siti Aisyah ${ }^{1}$, dan Laela Sari ${ }^{1}$ \\ ${ }^{1}$ Pusat Penelitian Limnologi LIPI, Jl. Raya Jakarta bogor km 46, Cibinong, 16911 \\ E-mail: yoyo@limnologi.lipi.go.id
}

Submitted 14April 2020. Reviewed 26May 2020. Accepted 2July 2020.

DOI: 10.14203/oldi.2020.v5i2.311

\begin{abstract}
Abstrak
Makrozoobentos merupakan salah satu biota akuatik yang sering digunakan untuk menilai kesehatan ekosistem sungai. Evaluasi rehabilitasi riparian dengan indikator makrozoobentos telah umum digunakan di beberapa negara. Tujuan dari penelitian ini adalah mengevaluasi dampak program rehabilitasi riparian sungai Ranggeh dan mengetahui parameter lingkungan yang memengaruhi komunitas makrozoobentos di Sungai Ranggeh. Penelitian ini dilakukan pada bulan Februari hingga September 2019. Pengambilan organisme makrozoobentos dilakukan dengan menggunakan hess sampler dengan luas area tersampling $0,2 \mathrm{~m}^{2}$. Evaluasi kemudian dilakukan dua bulan setelah rehabilitasi riparian selesai. Setelah rehabilitasi riparian dilakukan,terdapat perubahan pada metrik biologi jumlah taksa, kelimpahan, dan jumlah taksa Ephemeroptera, Plecoptera, dan Trichoptera (EPT). Metrik jumlah taksa dan EPT meningkat setelah direhabilitasi, namun kelimpahannya sedikit menurun. Metrik jumlah taksa berkorelasi positif terhadap parameter konduktivitas $(\mathrm{r}=0,8)$ dan korelasi negatif dengan turbiditas $(\mathrm{r}=-0,91)$ dan $\mathrm{pH}(\mathrm{r}=-0,77)$. Metrik EPT berkorelasi negatif dengan parameter turbiditas $(\mathrm{r}=-0,76)$ dan $\%$ embeddedness $(-0,94)$. Metrik kelimpahan total tidak sensitif terhadap parameter yang diukur dalam penelitian ini. Metrik biologi jumlah taksa dan EPT dapat digunakan dalam menilai dampak rehabilitasi habitat ekosistem sungai.
\end{abstract}

Kata Kunci: Makrozoobentos, Sungai Ranggeh, evaluasi, EPT, rehabilitasi.

\begin{abstract}
Evaluation of Riparian Rehabilitation in River River Usingthe Macrozoobenthos Community Indicator.Macrozoobenthos organism is one of aquatic biota which is often used to assess the river ecosystem healyh.The evaluation of riparian habitat rehabilitation using benthic macroinvertebrates has been commonly used in many countries. The purposes of this study were to evaluate the impact of Ranggeh river riparian rehabilitation and to determine environmental parameters that influenced benthic macroinvertebrate communities in Ranggeh River. This research was conductedfrom February to September 2019. Benthic macroinvertebratesamples were collected using Hess Sampler in a $0.2 \mathrm{~m}^{2}$ sampling area. This evaluation was carried out after two months since the rehabilitation of riparian habitat completed. The results showed that rehabilitation of the riparian habitat has changed the community, in the aspects of biological metrics of taxa number, abundance, and taxa numbersof Ephemeroptera, Plecoptera, and Trichoptera (EPT). Furthermore, the taxa number and EPT metrics increased after habitat rehabilitation, however the abundance decreased slightly. In addition, the taxa number metric was positively correlated with conductivity parameter $(r=0.8)$,
\end{abstract}


but negatively correlatedto turbidity $(\mathrm{r}=-0.91)$ and $\mathrm{pH}(\mathrm{r}=-0.77)$. Meanwhile, the EPT metric was negatively correlated with turbidity parameters $(\mathrm{r}=-0.76)$ and $\%$ embeddedness $(\mathrm{r}=-0.94)$. The total abundance metric was not sensitive to the parameters measured in this study. Meanwhile, biological metrics for taxa number and EPT can be used to assess rehabilitation success of river ecosystem habitats.

Keyword: Benthic macroinvertebrates, river, evaluation, EPT, rehabilitation.

\section{Pendahuluan}

Zona riparian memiliki peran yang sangat penting bagi ekosistem akuatik. Zona riparian dapat didefinisikan sebagai zona peralihan antara ekosistem terestrial dan akuatik yang secara teratur dipengaruhi oleh air tawar. Biasanya zona tersebut memanjang dari bagian tepi sungai hingga menuju ke arah hulu. Karakteristik dari zona tersebut adalah adanya dominansi tumbuhan yang mampu beradaptasi dengan lingkungan basah. Beberapa fungsi penting dari zona riparian antara lain: habitat bagi banyak flora dan fauna, sumber energi untuk biota akuatik melalui masukan materi organik allochtonous, barier untuk mencegah banjir, erosi, maupun sedimentasi ke perairan, penyerap dan penyimpan air permukaan, dan merupakan filter alami dari nutrien ( $\mathrm{N}, \mathrm{P}, \mathrm{Si}, \mathrm{Ca}$, dan $\mathrm{Mg}$ ) maupun bahan polutan lainnya. Sebagai contoh: kemampuan zona riparian untuk menahan nitrogen $(\mathrm{TN})$ dari input lingkungan terestrial ke badan sungai dapat mencapai $67-89 \%$. Mengingat peran penting dari zona tersebut ke lingkungan, maka zona tersebut perlu dijaga kelestariannya dari aktivitas antropogenik (Decamps et al., 2009; NRC, 2002).

Sungai Ranggeh termasuk dalam ketegori sungai kecil dengan inlet dari Danau Maninjau. Sungai tersebut memiliki panjang sekitar $5,9 \mathrm{~km}$ dari hulu hingga muara serta merupakansalah satu jalur ruaya ikan asli danau (misal: Rasbora maninjau, Gobiopterus brachypterus, Tor sp.). Saat ini, kondisi riparian Sungai Ranggeh relatif terbuka dan banyak mengalami gangguan akibat longsor dan erosi saat musim hujan tiba. Banyak materi tanah yang tergerus dan mengendap di dasar sungai, sehingga habitat di dasar sungai cenderung homogen oleh sedimen halus (pasir) (Yustiawati et al., 2019). Oleh sebab itu, diperlukan upaya rehabilitasi riparian Sungai Ranggeh guna mencegah longsor maupun meningkatkan heterogenitas habitat di dasar sungai. Menurut Hines \& Hershey (2011) dan Miller et al. (2010), secara umum tujuan dari rehabilitasi habitat sungai yaitu: meningkatkan heterogenitas habitat maupun kandungan oksigen terlarut, meningkatkan diversitas, kelimpahan, dan biomassa organisme akuatik melalui peningkatan 106 hidrolik dan ketersediaan makanan. Salah satu bentuk rehabilitasi habitat sungai yaitu: pengaturan batu di dasar sungai yang disesuaikan dengan morfologi sungai (misalnya: jeram, lubuk, dan meander) (Hines \& Hershey, 2011). Sebagai upaya dalam rehabilitasi habitat riparian di Sungai Ranggeh, maka akan dilakukan pemasangan kawat bronjong dan pemasangan batu didasar sungai guna mempertahankan diversitas biota Sungai Ranggeh.

Organisme makrozoobentos sering digunakan sebagai indikator untuk memantau kualitas perairan akibat pencemaran, sedimentasi (Maneechan \& Prommi, 2015), maupun evaluasi suksesnya rehabilitasi habitat (BesacierMonbertrand et al., 2014; Miller et al., 2010). Organisme tersebut memiliki beberapa keunggulan dibandingkan biota lainnya antara lain: sifatnya yang relatif menetap, siklus hidup yang relatif panjang, sensitivitas yang bervariasi (sensitif hingga toleran), mampu mencerminkan perubahan spasial maupun temporal di perairan, dan memiliki peran penting dalam rantai makanan (trofik) (Spänhoff \& Arle, 2007; Chessman, 2003; Barbour et al., 1999; Reice \& Wohlenberg,1993).

Serangga akuatik merupakan salah satu komponen dari komunitas makrozoobentos memiliki peran dalam dinamika ekologi ekosistem sungai dan secara luas dimanfaatkan sebagai bioindikator perairan (Stoyanova et al., 2014). Dari sekian banyak metrik biologi yang melibatkan serangga sebagai indikator, metrik jumlah taksa Ephemeroptera, Plecoptera, dan Trichoptera (EPT) paling sering dipilih untuk mengategorikan status gangguan pada ekosistem akuatik. Ketiga taksa tersebut relatif sensitif terhadap adanya perubahan kualitas air dan habitat di perairan. Pada beberapa kasus, dampak dari aktivitas antropogenik di sekitar sungai dapat menyebabkan perubahan pada jumlah taksa EPT. Oleh sebab itu kemunculan dari tiga taksa hewan tersebut biasanya mencerminkan kondisi perairan yang baik (minimnya gangguan pada ekosistem akuatik) (Hamid \& Rawi, 2017; Stoyanova et al., 2014; Besacier-Monbertrand et al., 2014; Hamid \& Rawi, 2011). Karena sensitivitas dari metrik biologi EPT ini yang baik terhadap adanya 
gangguan ekologi di perairan, maka pada penelitian ini akan digunakan untuk evaluasi kegiatan rehabilitasi Sungai Ranggeh.

Tujuan dari penelitian ini adalah mengevaluasi dampak dari program rehabilitasi riparian di Sungai Ranggeh terhadap komunitas makrozoobentos dan mengetahui parameter lingkungan yang memengaruhi komunitas makrozoobentos di sungai tersebut.

\section{Metodologi}

\section{Deskripsi lokasi penelitian}

Penelitian ini dilakukan di lima titik stasiun pengambilan sampel (Gambar 1). Stasiun situs rujukan (SR1) merupakan bagian hulu Sungai Ranggeh yang mewakili daerah dengan gangguan aktivitas antropogenik (pertanian) ringan dan berlokasi dekat dengan hutan. Stasiun 2 (SR2) merupakan lokasi yang mewakili daerah pertanian. Stasiun 3 (SR3) merupakan daerah campuran antara pemukiman penduduk dan pertanian. Stasiun 4 (SR4) dan 5 (SR5) merupakan bagian hilir dari sungai Ranggeh yang mewakili daerah pertanian dan pemukiman dekat dengan Danau Maninjau dan merupakan target rehabilitasi habitat riparian. Deskripsi masing- masing stasiun pengamatan ditampilkan dalam Tabel 1.

\section{Desain penelitian}

Desain penelitian yang digunakan dalam penelitian ini menggunakan pendekatan survei $e x$ post facto. Dasar sistematika penelitian adalah evaluasi struktur komunitas makrozoobentos sebelum dan setelah dilakukan rehabilitasi habitat riparian. Rehabilitasi riparian Sungai Ranggeh dilakukan dengan memasang kawat bronjong yang diisi dengan batu di bagian pinggir sungai dan penanaman batu berukuran bongkah/cobble ( $\Phi \quad 6,5 \mathrm{~cm}-25 \mathrm{~cm}$ ) di dasar sungai tempat pemasangan kawat bronjong. Pemasangan kawat bronjong tidak dilakukan di semua bagian tepi sungai, namun diprioritaskan hanya pada area yang rawan longsor. Ukuran kawat bronjong yang dipasang menyesuaikan dengan luas daerah yang terkena dampak oleh erosi. Kawat bronjong berukuran $40 \mathrm{~m} \times 1 \mathrm{~m} \times 1 \mathrm{~m}$ dipasang di stasiun SR4, sedangkan di stasiun SR5 berukuran $20 \mathrm{~m}$ $\mathrm{x} 1 \mathrm{~m} \times 1 \mathrm{~m}$. Jumlah total kawat bronjong yang diperlukan sebanyak 30 lembar. Pelaksanaan rehabilitasi riparian dilakukan di awal bulan Juni 2020, sedangkan evaluasi dampak baru dilakukan di bulan Juli dan Agustus 2020.

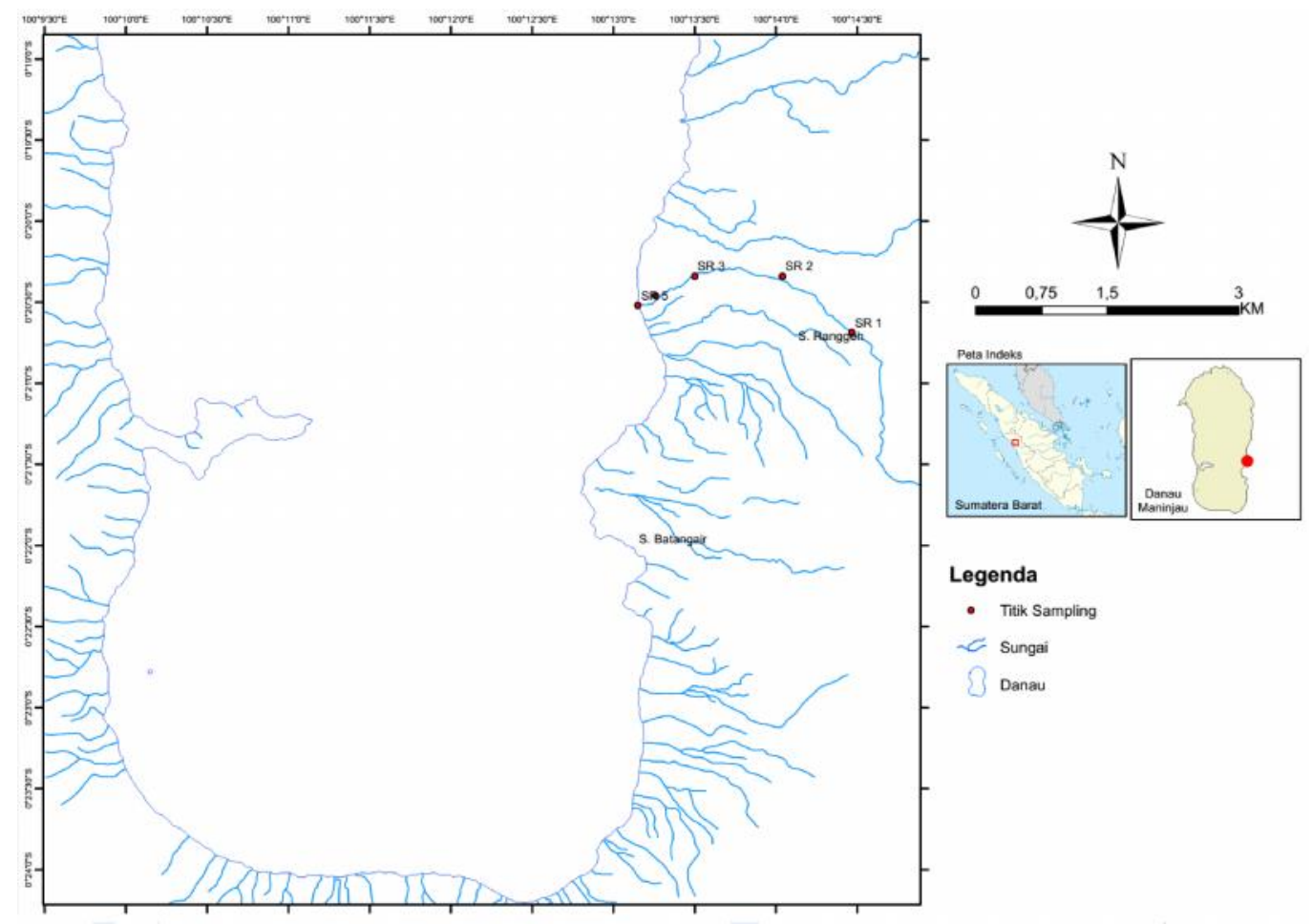

Gambar 1. Titik pengambilan sampel untuk penilaian komunitas makrozoobentos dan kualitas air di Sungai Ranggeh.

Figure 1. Sampling sites for analyzing macrozoobenthic assemblages and water qualities in Ranggeh River. 
Tabel 1. Karakteristik habitat di setiap titik sampling.

Table 1. Habitat characteristics at each of sampling sites.

\begin{tabular}{|c|c|c|}
\hline No & Station & Characteristics \\
\hline 1 & SR1 & $\begin{array}{l}\text { It is an upstream part of the Ranggeh River, with an altitude of } \\
810 \mathrm{~m} \text { above sea level. The right side of the river is a rice } \\
\text { fields and the left side is a forest. This site is a source of } \\
\text { irrigation for rice fields in the downstream. Water velocity is } \\
\text { an average of } 0.18 \mathrm{~m}^{3} / \mathrm{Sec} \text {. Substrates are dominated by large } \\
\text { and small rocks. Water is clear with low stresses from } \\
\text { agricultures. }\end{array}$ \\
\hline 2 & SR2 & $\begin{array}{l}\text { This site is } \pm 500 \text { meter below the SR } 1 \text { with an altitude of } 625 \\
\text { above sea level. The average water velocity is } 0.04 \mathrm{~m}^{3} / \mathrm{Sec} \text {. } \\
\text { There are many large and small rocks on the right and left of } \\
\text { the river. The water looks murky due to the impact of } \\
\text { agricultural activities. }\end{array}$ \\
\hline 3 & SR3 & $\begin{array}{l}\text { This site is near the bridge, approximately } 700 \text { meter from } \\
\text { SR } 1 \text { with a height of } 530 \mathrm{~m} \text { above sea level. The velocity is } \\
\text { about } 0,006 \mathrm{~m}^{3} / \mathrm{Sec} \text {. There are many sandbanks in some } \\
\text { places. The right side is residential areas while the left side is } \\
\text { rice fields. The river is often dry following irrigation } \\
\text { regulation. }\end{array}$ \\
\hline 4 & SR4 & $\begin{array}{l}\text { This site is about } 5300 \mathrm{~m} \text { from SR } 1 \text { with a height of } 450 \mathrm{~m} \\
\text { above sea level. The width of river is about } 1.2 \mathrm{~m} \text { with the } \\
\text { water velocity of } 0.03 \mathrm{~m}^{3} / \mathrm{Sec} \text {. The right and left of the river } \\
\text { are rice fields. Tree trunks sink and block the flow of the river. } \\
\text { The water is relatively clear. Substrates are dominated by } \\
\text { sand. The edge of the river is a former landslide. }\end{array}$ \\
\hline 5 & SR5 & $\begin{array}{l}\text { This site is about } 5700 \mathrm{~m} \text { from SR1 with an altitude of } 449 \mathrm{~m} \\
\text { above sea level. The water velocity is approximately } 0.04 \mathrm{~m}^{3} \\
\text { /Sec. The left and right sides of the river are rice fields. Marks } \\
\text { of landslides are visible on the right and left bank. There are } \\
\text { many sandbanks with small rocks. }\end{array}$ \\
\hline
\end{tabular}

\section{Teknik pengambilan contoh}

Sampling dilakukan pada bulan Februari hingga Agustus 2019. Sampling pada bulan Februari dan Maret mewakili stasiun yang belum direhabilitasi habitat ripariannya, sedangkan sampling pada bulan Juli dan Agustus mewakili stasiun yang sudah direhabilitasi (SR4.2 dan SR5.2).

Pengukuran kondisi kualitas air Sungai Ranggeh dilakukan secara langsung di setiap stasiun pengamatan dengan menggunakan alat Water Quality Checker (WQC) Horiba U-50. Parameter yang diukur secara langsung di lapangan antara lain: oksigen terlarut (DO), $\mathrm{pH}$, suhu, konduktivitas, total padatan terlarut (TDS), dan turbiditas. Pengukuran dilakukan sebanyak 108 tiga kali ulangan. Lebar Sungai Ranggeh selama

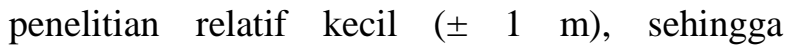
pengambilan sampel air untuk analisis nutrien (Total Nitrogen dan Total Fosfor) dilakukan di bagian tengah sungai. Sampel air yang dibutuhkan untuk analisis TN dan TP sebanyak $250 \mathrm{ml}$. Analisis parameter total fosfor (TP) dan total nitrogen (TN) dilakukan di laboratorium Puslit Limnologi-LIPI dengan menggunakan alat spektrofotometer. Pengukuran TN dilakukan dengan menggunakan metode brucine (TN), sedangkan TP dilakukan dengan menggunakan analisis ammonium molybdate (APHA, 2005). Analisis \% pasir dilakukan dengan mengambil 500 g sampel sedimen menggunakan sekop kecil. Persentase pasir di sedimen ditentukan dengan 
menggunakan metode granulometry. Pemisahan pasir dilakukan dengan menggunakan saringan bertingkat (ukuran pori dari $2 \mathrm{~mm}-0,063 \mathrm{~mm}$ ) (Gee \& Bauder, 1986). Penilaian persentase banyaknya batu yang tertanam di dasar sungai ( $\%$ embeddedness) dilakukan secara kualitatif di masing masing stasiun pengamatan.

Di setiap stasiun pengamatan, pengambilan sampel makrozoobentos dilakukan sebanyak tiga kali (pinggir kiri, tengah, dan pinggir kanan) dan dikomposit menjadi satu sampel (luas area 0,2 $\mathrm{m}^{2}$ ). Pengambilan organisme makrozoobentos dilakukan dengan menggunakan alat Hess Sampler berdiameter $30 \mathrm{~cm}$ dengan ukuran pori $0,5 \mathrm{~mm}$. Substrat di dalam area Hess sampler diaduk dengan tangan dan batu yang ada di dalam, disikat dengan sikat gigi agar organisme makrozoobentos dapat hanyut dan tertahan dalam saringan. Sampel dimasukkan dalam botol plastik yang bervolume $250 \mathrm{ml}$, kemudian diawetkan dengan menggunakan larutan alkohol 96\%. Proses sortir dan identifikasi dilakukan di laboratorium Puslit Limnologi-LIPI. Sortir organisme makrozoobentos dilakukan di bawah mikroskop stereo dengan pembesaran 80x. Identifikasi makrozoobentos diusahakan hingga tingkat genus dengan menggunakan kunci identifikasi Merritt \& Curnmins (2019) dan Thorp \& Covich (1991).

\section{Analisis Data}

Kesamaan struktur komunitas makrozoobentos antara situs rujukan, situs uji sebelum dan sesudah rehabilitasi dievaluasi dengan menggunakan rumus koefisien persen kesamaan (similarity) dari Czekanowski (1909) sebagai berikut:

$$
P S C_{i j}=200 \frac{\sum_{k=1}^{n} \min \left(X_{i k} \cdot X_{j k}\right)}{\sum_{k=1}^{n}\left(X_{i k}+X_{i j}\right)}
$$

Keterangan:

$\mathrm{PSC}_{\mathrm{ij}}=$ Koefisien persen kesamaan

$\min =$ Nilai minimal diri kedua nilai $X_{\mathrm{i}}$ dan $X_{\mathrm{j}}$. ${ }_{\mathrm{i}}$ dan $_{\mathrm{j}}=$ menunjukkan dua baris (kasus) dari

matriks data.

$\mathrm{k}=$ menunjukkan kolom (variabel).

$\mathrm{X}_{\mathrm{ik}} \quad=$ data dalam kolom ke $\mathrm{k}$ baris ke $\mathrm{i}$.

$\mathrm{n} \quad=$ jumlah total variabel.

Penghitungan koefisien persen kesamaan dilakukan dengan bantuan perangkat lunak MVSP versi 3.22 (Kovach, 2010).

Evaluasi rehabilitasi riparian dilakukan dengan menggunakan metrik biologi yang meliputi jumlah taksa, kelimpahan total, dan jumlah taksa EPT. Analisis korelasi pearson product momentdigunakan untuk melihat sensitivitas metrik biologi dengan parameter kualitas air Sungai Ranggeh. Analisis korelasi dilakukan dengan menggunakan perangkat lunak STATISTICA versi 10 (Statsoft, 2011).

\section{Hasil}

Hasil rerata pengukuran kualitas air sebelum dan sesudah direhabilitasi menunjukkan parameter kualitas air menuju ke hilir yang cenderung meningkat (TDS, konduktivitas, suhu, turbiditas, TN, TP), kecuali $\%$ pasir, $\mathrm{pH}$, dan $\%$ embeddedness yang cenderung menurun (Tabel 2). Setelah dilakukan rehabilitasi, parameter TDS, TN, dan konduktivitas meningkat. Bahkan TDS cenderung meningkat secara drastis hampir 1,5 kali lipat dari sebelum dilakukan rehabilitasi (4.1 dan 5.1). Namun, \% embeddedness cenderung menurun karena penambahan substrat batu di dasar perairan.

Hasil analisis jumlah taksa dan kelimpahan organisme makrozoobentos dari hulu (SR1) hingga hilir (SR5) adanya penambahan jumlah taksa makrozoobentos di lokasi yang telah direhabilitasi, yaitu SR4.2 dan SR5.2 (Gambar 2). Pada stasiun 4 terjadi penambahan 8 taksa (SR4.1 ke SR4.2), dan di stasiun 5 terjadi penambahan 5 taksa (SR5.1 ke 5.2). Rerata kelimpahan di stasiun 4 cenderung meningkat dari 116 individu $/ \mathrm{m}^{2}$ (SR4.1) menjadi 135 individu $/ \mathrm{m}^{2}$ (SR4.2), namun sebaliknya di stasiun cenderung menurun 251 individu/m $\mathrm{m}^{2}$ (SR5.1) menjadi 145 individu $/ \mathrm{m}^{2}$ (SR5.2).

Komposisi organisme makrozoobentos di Sungai Ranggeh menunjukkan adanya tujuh ordo insekta, cacing Oligochaeta, Hirudinida, dan Gastropoda (Lampiran 1). Rehabilitasi habitat menambah jenis makrozoobentos yang ditemukan, terutama dari golongan insekta (Plecoptera, Ephemeroptera, Trichoptera, Lepidoptera, Coleoptera, dan Hemiptera). Namun, jumlah jenis pada taksa Diptera dan Oligochaeta cenderung berkurang. Kondisi ini akanmemengaruhi pada rendahnya persen kesamaan komunitas makrozoobentos antara sebelum dengan sesudah direhabilitasi (Tabel 3). Keberadaan taksa insekta sensitif seperti Ephemeroptera, Plecoptera, dan Trichoptera (EPT) di stasiun SR4.2 dan SR5.2 merupakan sinyal positif akan berhasilnya program rehabilitasi habitat yang dilakukan. Setelah dilakukan rehabilitasi, struktur komunitas makrozoobentos penyusun stasiun 4.2 dan 5.2 cenderung sama, yang ditunjukkan oleh hasil analisis koefisien kesamaan sebesar $63,8 \%$ 
Tabel 2. Rerata hasil pengukuran kualitas fisika dan kimia air Sungai Ranggeh. SR4.1 dan SR5.1 adalah stasiun sebelum rehabilitasi, sedangkan SR4.2 dan SR5.2 adalah stasiun setelah rehabilitasi (rerata $\pm \mathrm{SD})$.

Table 2. Average measurement of physical and chemical water qualities at Ranggeh River. SR4.1 and SR5.1 are sites before rehabilitation, while SR4.2 and SR5.2 are sites after rehabilitation (mean \pm SD).

\begin{tabular}{|l|c|c|c|c|c|c|c|}
\hline \multirow{2}{*}{ Parameters } & \multicolumn{7}{|c|}{ Sampling Sites } \\
\cline { 2 - 9 } & SR1 & SR2 & SR3 & SR4.1 & SR 4.2 & SR 5.1 & SR5.2 \\
\hline TDS $(\mathrm{mg} / \mathrm{l})$ & $42.2 \pm 4$ & $77.1 \pm 3$ & $78.7 \pm 10$ & $82.1 \pm 14$ & $\mathbf{1 2 3} \pm 1.4$ & $80 \pm 15$ & $\mathbf{1 3 0} \pm 0.7$ \\
\hline pH & $7.8 \pm 0.5$ & $7.8 \pm 0.6$ & $7.9 \pm 0.6$ & $7.2 \pm 0.1$ & $7.1 \pm 0.2$ & $7.5 \pm 0.1$ & $7.1 \pm 0.2$ \\
\hline DO $(\mathrm{mg} / \mathrm{l})$ & $8.2 \pm 0.6$ & $7.9 \pm 0.5$ & $6.5 \pm 1.7$ & $6.1 \pm 1.1$ & $6.4 \pm 0.2$ & $6.1 \pm 0.6$ & $6.4 \pm 0.01$ \\
\hline $\begin{array}{l}\text { Conductivity } \\
\text { (mS/cm) }\end{array}$ & $0.098 \pm 0.03$ & $0.101 \pm 0.03$ & $0.117 \pm 0.02$ & $0.130 \pm 0.05$ & 0.189 & $0.128 \pm 0.05$ & $0.189 \pm 0.02$ \\
\hline Turbidity(NTU) & $9 \pm 5.6$ & $52.9 \pm 10$. & $168.5 \pm 30$ & $76.9 \pm 11$. & 16.3 & $79.8 \pm 15$. & 18 \\
\hline Temperature $\left({ }^{0} \mathrm{C}\right)$ & $21.5 \pm 0.34$ & $23.6 \pm 1.2$ & $24.8 \pm 2.1$ & $27.1 \pm 0.7$ & $27.6 \pm 0.5$ & $27.8 \pm 1.4$ & $27.4 \pm 0.1$ \\
\hline TN (mg/l) & $0.54 \pm 0.4$ & $0.68 \pm 0.3$ & $1.12 \pm 0.6$ & $0.46 \pm 0.2$ & $0.69 \pm 0.18$ & $0.41 \pm 0.01$ & $0.96 \pm 0.32$ \\
\hline TP (mg/l) & $0.05 \pm 0.05$ & $0.07 \pm 0.05$ & $0.08 \pm 0.02$ & $0.05 \pm 0.02$ & $0.07 \pm 0.03$ & $0.06 \pm 0.02$ & $0.08 \pm 0.05$ \\
\hline \% Sand & $92,2 \pm 0.28$ & $85,8 \pm 6.2$ & 84,6 & $91,7 \pm 0.9$ & $91,5 \pm 0.14$ & $91,7 \pm 1.0$ & $91,5 \pm 0.1$ \\
\hline$\%$ Embeddedness & 20 & 30 & 60 & 50 & 35 & 55 & 40 \\
\hline
\end{tabular}

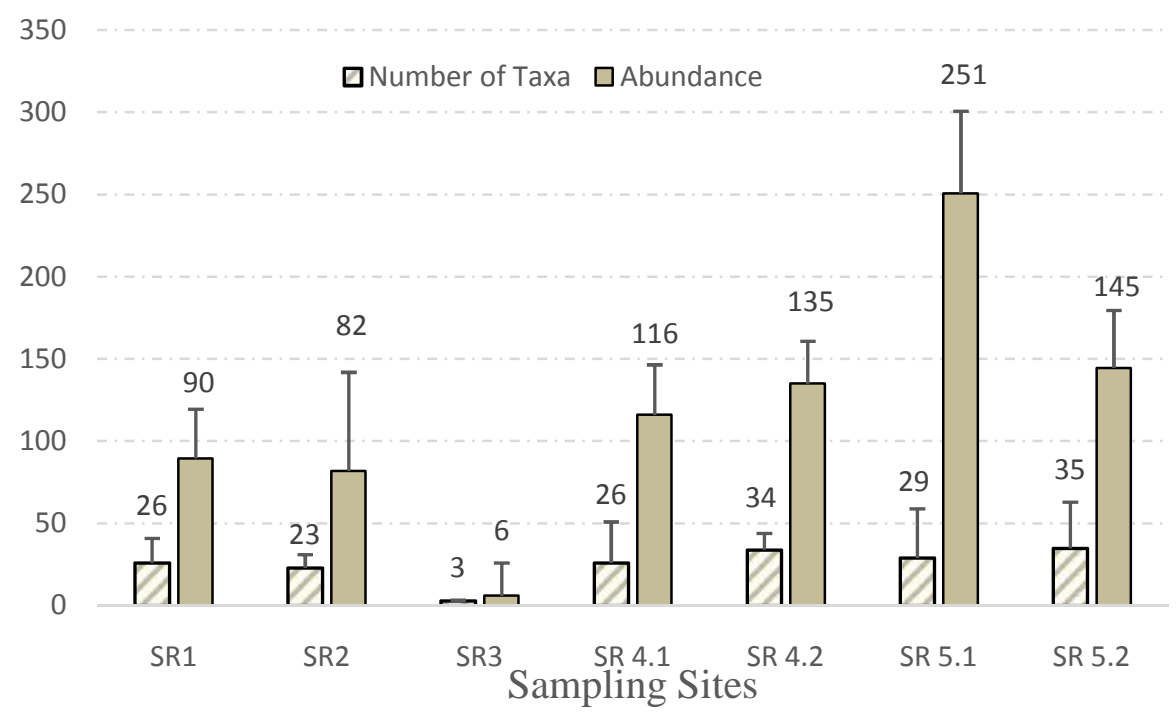

Gambar 2. Jumlah taksa dan kelimpahan organisme makrozoobentos sebelum (SR4.1 dan SR5.1) dan setelah rehabilitasi riparian (SR4.2 dan SR5.2).

Figure 2. Number of taxa and abundance of benthic macroinvertebrates before (SR4.1 and SR5.1) and after riparian rehabilitation (SR4.2 and SR5.2). 
Tabel 3.Matriks persen kesamaan dari komunitas makrozoobentos sebelum (SR4.1 dan SR5.1) dan sesudah direhabilitasi (SR4.2 dan SR5.2).

Table 3. Percentage of similarity matrix of the benthic macroinvertebrate communities in the riparian river before (SR4.1 and SR5.1) and after rehabilitation (SR4.2 and SR5.2).

\begin{tabular}{|l|c|c|c|c|c|c|c|}
\hline & \multicolumn{7}{|c|}{ Sampling Sites } \\
\cline { 2 - 9 } & SR1 & SR2 & SR3 & SR 4.1 & SR4.2 & SR5.1 & SR5.2 \\
\hline SR1 & 100 & & & & & & \\
\hline SR2 & 61,224 & 100 & & & & & \\
\hline SR3 & 6,897 & 7,692 & 100 & & & & \\
\hline SR4.1 & 11,538 & 16,327 & 0 & 100 & & & \\
\hline SR4.2 & 36,667 & 45,614 & 5,405 & 33,333 & 100 & & \\
\hline SR5.1 & 21,818 & 26,923 & 12,5 & 76,364 & 41,27 & 100 & \\
\hline SR5.2 & 22,951 & 34,483 & 5,263 & 39,344 & 63,8 & 53,125 & 100 \\
\hline
\end{tabular}

Jumlah taksa EPT sebelum dan sesudah rehabilitasi riparian menunjukkan peningkatan yang signifikan (Gambar 3). Di stasiun SR4.1 terjadi peningkatan jumlah taksa EPT hingga 10 kali lipat (SR4.2) dan di stasiun SR5.1 terjadi peningkatan dua kali lipat (SR5.2). Jumlah taksa
EPT di stasiun SR 4.2 dan SR5.2 setelah direhabilitasi mendekati jumlah taksa EPT di bagian Hulu sebagai kontrol (SR1) maupun SR2 yang mencerminkan pengaruh dari aktivitas pertanian masih minim.

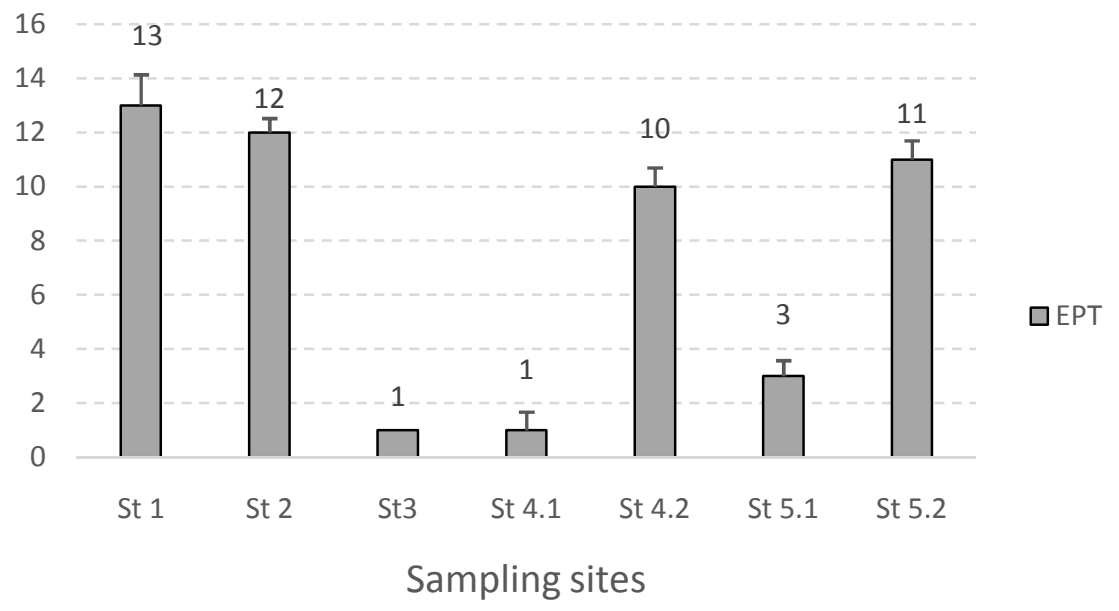

Gambar 3. Jumlah taksa EPT sebelum dan sesudah restorasi riparian di Sungai Ranggeh. Keterangan SR4.2 dan SR5.2 setelah direhabilitasi habitatnya.

Figure 3. Number of EPT taxa before and after riparian restoration in the Ranggeh River. Remarks SR4.2 and SR5.2 after the habitat rehabilitation.

Hasil analisis korelasi pearson product moment antara metrik biologi dengan parameter lingkungan yang diukur menunjukkan adanya sensitivitas metrik biologi jumlah taksa dan EPT (Tabel 4). Metrik jumlah taksa berkorelasi positif terhadap parameter konduktivitas $(r=0,8)$ dan korelasi negatif dengan turbiditas $(r=-0,91)$ dan
$\mathrm{pH}(\mathrm{r}=-0,77)$. Metrik biologi EPT berkorelasi negatif dengan parameter turbiditas $(r=-0,76)$ dan $\%$ embeddedness $(\mathrm{r}=-0,94)$. Metrik kelimpahan total tidak menunjukkan adanya korelasi terhadap parameter yang diukur dalam penelitian ini. 
Tabel 4. Korelasi pearson product moment antata metrik biologi dengan parameter lingkungan.

Table 4. Pearson product moment correlation between biological metrics with environmental parameters.

\begin{tabular}{|l|c|c|c|}
\hline Parameters & Taxa Number & Abundance & EPT \\
\hline TDS & 0,46 & 0,25 & 0,07 \\
\hline pH & $-0,77$ & $-0,56$ & 0,01 \\
\hline DO & $-0,10$ & $-0,42$ & 0,52 \\
\hline Conductivity & $-0,80$ & 0,50 & 0,27 \\
\hline Turbidity & $-0,91$ & $-0,47$ & $-0,76$ \\
\hline Temperature & 0,40 & 0,60 & $-0,45$ \\
\hline TN & $-0,47$ & $-0,62$ & 0,02 \\
\hline TP & $-0,51$ & $-0,27$ & $-0,19$ \\
\hline \% Sand & $-0,14$ & 0,07 & $-0,45$ \\
\hline \% Embeddedness & $-0,47$ & 0,08 & $-0,94$ \\
\hline
\end{tabular}

\section{Pembahasan}

Paska rehabilitasi riparian di Sungai Ranggeh menunjukkan adanya perubahan kualitas air yang cukup mencolok, khususnya pada parameter TDS, TN, konduktivitas, dan TP. Konsentrasi TN dan TP di Sungai Ranggeh memiliki kisaran rerata sebesar $(0,69-0,96 \mathrm{mg} / \mathrm{l})$ dan $(0,07-0,08 \mathrm{mg} / \mathrm{l})$ paska rehabilitasi. Peningkatan parameter tersebut di atas dapat disebabkan oleh beberapa faktor antara lain: 1). Selama pengerjaan penguatan pinggir sungai dengan kawat bronjong melibatkan proses clearing vegetasi riparian. Adanya proses pembusukan sisa clearing vegetasi riparian dapat meningkatkan kandungan nutrien di perairan. Ekawati (2005) menyebutkan kandungan $\mathrm{N}$ dari proses pembusukan jerami mencapai $0,8-1,0 \%$. Juwitanti et al. (2013) menunjukkan kandungan nitrat dan fosfat dari pembusukan daun eceng gondok sebesar $1,599-2,053 \mathrm{mg} / \mathrm{l}$ dan $0,025-$ $0,099 \mathrm{mg} / \mathrm{l} .2$ ). Awal musim kemarau terjadi di bulan Juli dan Agustus yang berakibat pada debit sungai yang berkurang. Kondisi ini akan berpengaruh pada tingginya parameter TDS, konduktivitas, TN, dan TP di perairan. Adanya dominasi aktivitas pertanian maupun pemukiman penduduk di stasiun SR3 hingga SR5 berkontribusi dalam memberikan pengayaan nutrien ke Sungai Ranggeh. Yanti (2017) menunjukkan kandungan TN dan TP di Sungai Kahayan yang didominasi oleh pertanian dan perkebunan dapat mencapai $1.53 \mathrm{mg} / \mathrm{l}$ dan 1,45 mg/l. Hanafi \& Purnama (2012) menyebutkan kandungan TN dan TP di saluran air yang belum terpolusi oleh aktivitas antropogenik (hutan) biasanya kurang dari $0,55 \mathrm{mg} / \mathrm{l}$ dan $0,04 \mathrm{mg} / \mathrm{l}$, sedangkan daerah yang sudah terpolusi bisa melebihi $0,67 \mathrm{mg} / \mathrm{l}$ (TN) dan $0,28 \mathrm{mg} / \mathrm{l}$ (TP). Penggunaan pupuk dapat meningkatkan konsentrasi TN dan TP di sungai akibat pelindian (Frame \& Reiter 2013). Kandungan N di pupuk urea bisa mencapai 46\% (Saragih et al., 2013), sedangkan P di pupuk SP 36 sebesar 36\% (Kasno 2009). Penggunaan deterjen dan limbah pemukiman penduduk juga berkontribusi dalam meningkatkan TN, TP, konduktivitas, dan TDS di sungai. Putri et al. (2014) menyebutkan senyawa fosfat dalam bentuk tripolifosfat merupakan komponen penting penyusun deterjen bubuk. Limbah organik dari feses dan urin manusia dapat menyumbang $\mathrm{N}$ sebesar 10-20\% dan $\mathrm{P}$ sebesar $20-50 \%$ di feses dan $65 \%$ di urin.

Nilai parameter turbiditas di stasiun SR1 hingga SR5 memiliki kisaran yang luas (2-230 NTU). Sampling pada kondisi sebelum rehabilitasi dilakukan pada musim hujan (bulan Februari dan Maret). Air run off membawa materi tersuspensi ke saluran sungai yang berdampak langsung pada tingginya parameter turbiditas dibandingkan saat musim kemarau (Agustus dan September). Quinn et al. (1992) menyebutkan nilai turbiditas di atas 23 NTU mampu menurunkan kekayaan taksa dan kepadatan sebagian besar organisme makrozoobentos. Dalam tabel 3 juga menunjukkan adanya korelasi negatif antara jumlah taksa dengan parameter turbiditas $(r=-0,91)$. Partikel tersuspensi dapat memberikan dampak negatif bagi biota akuatik antara lain: menghalangi organ respirasi, merusak habitat pemijahan, menutupi substrat untuk mendapatkan makanan, menurunkan kandungan 
oksigen terlarut di ruang interstitial sedimen, dan menganggu perkembangan telur (Jones et al., 2012; Kemp et al., 2011). Dengan kondisi seperti itu, maka parameter turbiditas berpotensi sebagai ancaman bagi kehidupan makrozoobentos di Sungai Ranggeh.

Hasil pengukuran TN dan TP di Sungai Ranggeh menunjukkan kisaran berturut-turut 0.46-1.12 mg/l dan 0,05-0,08 mg/l. Di stasiun SR4 dan SR5 konsentrasi TN dan TP setelah dilakukan rehabilitasi cenderung meningkat hingga $0.96 \mathrm{mg} / \mathrm{l}$ dan $0.08 \mathrm{mg} / \mathrm{l}$ bila dibandingkan dengan kondisi sebelum rehabilitasi. Konsentrasi TN berkaitan dengan toleransi makrozoobentos. Ashton et al. (2013) menyebutkan makrozoobentos yang hidup di perairan dengan $\mathrm{TN} \leq 1,68 \mathrm{mg} / \mathrm{l}$ dikategorikan sebagai organisme sensitif, sedangkan apabila $\mathrm{TN}>1,68 \mathrm{mg} / \mathrm{l}$ termasuk organisme toleran. Berdasarkan pendapat peneliti tersebut secara umum makrozoobentos yang hidup di Sungai Ranggeh masih didominasi oleh taksa yang sensitif terhadap parameter TN. Sultana et al. (2019) menunjukkan kekayaan taksa makrozoobentos yang tinggi di Sungai Torrens (72 taksa) dan Onkaparinga (74 taksa) dengan konsentrasi TN berturut turut $4,450 \mathrm{mg} / \mathrm{l}$ dan $5,6 \mathrm{mg} / \mathrm{l}$, serta TP $0,87 \mathrm{mg} / \mathrm{l}$ dan $0,56 \mathrm{mg} / \mathrm{l}$. Barlow-Busch et al. (2006) menyebutkan pengayaan TP oleh aktivitas antropogenik di perairan $>30 \mu \mathrm{g}$ P/l secara signifikan mampu meningkatkan biomassa alga bentik di sungai. Dari nilai konsentrasi TP tersebut di atas, maka memungkinkan tercukupinya biomassa alga dari Sungai Ranggeh sebagai sumber pakan alami bagi makrozoobentos.

Metrik kelimpahan dan jumlah taksa makrozoobentos dari hulu (SR1) hingga hilir (SR5) cenderung meningkat. Kondisi ini mungkin erat kaitannya dengan suhu air yang semakin ke hilir semakin meningkat. Ruzickova et al. (2017) menyebutkan pengaruh suhu air pada epilithon yang bersifat thermophilic akan meningkatkan biomassa, kekayaan taksa, dan diversitasnya di suhu $25-30{ }^{0} \mathrm{C}$, dan akan menurun ketika suhu melebihi $30{ }^{\circ} \mathrm{C}$. Berdasarkan suhu air di Sungai Ranggeh maka epilithon di sungai tersebut masih sesuai untuk tumbuh secara maksimal.

Persentase banyaknya batu yang tertanam di dasar sungai (embeddedness) dapat menurunkan jumlah taksa dan EPT dari makrozoobentos di Sungai Ranggeh. Embeddedness substrat dihasilkan dari endapan sedimen yang mengisi ruang interstitial di antara batuan dan dapat mengubah kualitas habitat (Jun et al. 2011). Metrik biologi kekayaan taksa berkorelasi negatif dengan $\mathrm{pH}(\mathrm{r}=-0,77)$, konduktivitas $(\mathrm{r}=-0.8)$, dan turbiditas $(\mathrm{r}=-0.91)$. Metrik EPT berkorelasi negatif dengan parameter turbiditas $(\mathrm{r}=-0,76)$ dan $\%$ embeddedness $(\mathrm{r}=$ 0,94). Metrik biologi EPT menunjukkan lebih stabil dan lebih sensitif dalam mendeteksi gangguan pada ekosistem lotik daripada kekayaan taksa (Brabec et al., 2004). Penelitian Jun et al. (2011) di Sungai Song dan Odae, Korea menunjukkan hal yang serupa yaitu adanya korelasi negatif antara parameter turbiditas dengan EPT $(r=0,57)$. Hamid \& Rawi (2011) menyebutkan nilai EPT di Sungai Teroi Malaysia cenderung rendah ketika \% embeddedness di sungai mencapai 50-75\%. Kekayaan taksa serangga air akan cenderung rendah ketika substrat dasar flat homogen, karena menyulitkan hewan tersebut untuk menempel dan ketersediaan materi organik yang rendah sebagai pakan. Kompleksitas fisik substrat yang memiliki permukaan kasar dapat digunakan untuk membantu melekatnya organisme makrozoobentos dan bertahan dari kuatnya arus air (Molukwu et al., 2014). Ruang interstitial di antara batuan dapat berfungsi sebagai tempat untuk berlindung maupun mencari makan bagi banyak makrozoobentos. Sedimentasi yang terjadi di sungai akan mengisi ruang interstitial yang berakibat pada rendahnya kandungan oksigen pada habitat tersebut (Jones et al., 2012).

Fluktuasi kelimpahan organisme makrozoobentos di Sungai Ranggeh setelah dilakukan rehabilitasi menunjukkan pola yang berbeda antara SR4.2 dan SR5.2 (Gambar 2). Namun pada pola tersebut masih terlihat kelimpahan makrozoobentos di stasiun yang sama setelah direhabilitasi masih lebih tinggi dibandingkan sebelum direhabilitasi. Kondisi ini kemungkinan disebabkan oleh masih terbatasnya waktu untuk terjadinya rekolonisasi organisme makrozoobentos secara maksimal (pengamatan hanya 2 bulan). Biasanya waktu suksesi dari komunitas makrozoobentos akan terlihat lebih jelas setelah 1 tahun dan selama tidak ada gangguan ekstrim lainnya (pencemaran maupun perusakan habitat oleh sedimentasi). Miller et al. (2010) menyebutkan restorasi habitat setelah 1 tahun memiliki pengaruh positif yang signifikan pada jumlah kekayaan taksa maupun kelimpahan makrozoobentos. Pada area habitat sungai yang telah dilakukan rehabilitasi, terdapat peningkatan rerata jumlah kekayaan taksa makrozoobentos sebesar $14,2 \%$ dan peningkatan kelimpahan sebesar $28 \%$. 
Metrik persen kesamaan menunjukkan perubahan pada struktur komunitas sebelum dan setelah direhabilitasi (stasiun SR4 dan SR5). Adanya penambahan substrat berupa batu bongkah/cobble diduga meningkatkan jumlah taksa dari makrozoobentos. Setelah dilakukan rehabilitasi mulai muncul makrozoobentos yang biasa berasosiasi dengan batu seperti: Trichoptera (Ceratopsyche, Cheumatopsyche, Macrostemum), Ephemeroptera (Plat-baetis, Baetis, Caenis), dan Plecoptera (Neoperla). Kondisi ini merupakan sinyal positif dari sisi konservasi, karena keberadaan hewan EPT umumnya sensitif terhadap pencemaran, sedimentasi maupun gangguan lainnya pada ekosistem akuatik (Cobo et al., 2017). Bhandari et al.(2018) menyebutkan batu ukuran cobble dan pebble memiliki substrat yang lebih stabil guna mendapat makanan, perlindungan dari predator, maupun pengaruh fisik hidrolika (misal: kuatnya arus). Oleh sebab itu, keanekaragaman makrozoobentos tertinggi terdapat pada batu ukuran cobble. Molokwu et al. (2014) menyebutkan larva serangga famili Ephemeroptera (Caenidae), Trichoptera (Hydropsychidae), dan Plecoptera (Perlidae) memiliki preferensi untuk berasosiasi dengan substrat batu. Cacing Oligochaeta dan larva Diptera Chironomidae memiliki preferensi untuk hidup di sedimen (Cesar \& Henry, 2017).

Metrik biologi EPT dan jumlah taksa biasa digunakan untuk menyusun kriteria biologi maupun penilaian gangguan pada ekosistem akuatik. Penelitian ini menunjukkan adanya korelasi positif antara jumlah taksa dengan konduktivitas. Nilai konduktivitas menunjukkan kemampuan suatu larutan untuk menghantarkan arus listrik. Besarnya nilai konduktivitas ini biasanya erat kaitan dengan pencemaran (Arlindia \& Afdal, 2015). Banyaknya ion yang terkandung dalam larutan dipengaruhi oleh mineral maupun padatan terlarut di dalamnya (Irwan \& Afdal, 2016). Semakin ke arah hilir nilai konduktivitas cenderung meningkat akibat masukan air permukaan, limbah pertanian maupun perumahan, dan pelarutan mineral batuan dari badan sungai (Arlindia \& Afdal, 2015). Selama kandungan ion yang terkandung di perairan masih dapat ditoleransi oleh biota makrozoobentos, maka ada kemungkinan jumlah taksa dari hewan tersebut dapat meningkat seperti yang terjadi di Sungai Ranggeh. Nilai konduktivitas kurang dari 0,3 $\mathrm{mS} / \mathrm{cm}$ dapat melindungi sebagian besar kehidupan biota akuatik di Sungai Appalachian tengah (US-EPA, 2017). Benetti et al. (2012) menunjukkan nilai konduktivitas $0,186 \mathrm{mS} / \mathrm{cm}$ berkorelasi negatif dengan kekayaan taksa. Karena sebagian besar hasil pengukuran konduktivitas masih dibawah $0,186 \mathrm{mS} / \mathrm{cm}$ kecuali di SR 4.2 dan $5.2(0,189 \mathrm{mS} / \mathrm{cm})$, maka masih memungkinkan makrozoobentos mampu beradaptasi dengan baik yang ditandai dengan jumlah taksa yang meningkat ke arah hilir.

Pengaruh $\mathrm{pH}$ pada kehidupan makrozoobentos memiliki peran penting dalam pengaturan pertukaran ion, respirasi, dan absorbsi kalsium untuk perkembangan eksoskeleton (Anonymous, 2004). Penelitian ini menunjukkan korelasi positif antara jumlah taksa makrozoobentos dengan parameter $\mathrm{pH}(\mathrm{r}=0,77)$. Penelitian Kulberg (1992) menunjukkan adanya korelasi positif jumlah taksa makrozoobentos dengan $\mathrm{pH}\left(\mathrm{r}^{2}=0.492\right)$ dan warna air asam humat $(\mathrm{p}<0,05)$. Namun untuk metrik kelimpahan memiliki korelasi yang lemah. Nilai $\mathrm{pH}<5,5$ dapat menurunkan secara drastis jumlah taksa makrozoobentos. Nilai pH air antara 6,5-9 dapat mendukung kehidupan sebagian besar hewan akuatik dalam jangka waktu yang relatif panjang (Anonymous, 2004). Nilai pH Sungai Ranggeh yang berkisar 6,9-8,6 masih mendukung kehidupan makrozoobentos.

\section{Kesimpulan}

Dari penelitian ini dapat disimpulkan antara lain bahwa evaluasi rehabilitasi habitat Sungai Ranggeh dengan indikator organisme makrozoobentos dapat mencerminkan adanya perubahan struktur komunitas berupa peningkatan jumlah taksa makrozoobentos dan EPT, namun untuk kelimpahannya relatif berfluktuasi setelah dilakukan rehabilitasi. Beberapa organisme yang tergolong sensitif seperti: Ephemeroptera, Plecoptera, dan Trichoptera mulai menunjukkan adanya kolonisasi sehingga mampu meningkatkan jumlah taksa secara keseluruhan. Beberapa faktor lingkungan penting seperti $\mathrm{pH}$, turbiditas, konduktivitas, dan \% embeddedness berkontribusi dalam memengaruhi metrik biologi dari struktur komunitas (jumlah taksa dan EPT). Implikasi dari rehabilitasi habitat ini dapat menciptakan fungsional feeding location baru yang belum ada sebelumnya pada lokasi yang dilakukan rehabilitasi.

\section{Persantunan}

Ucapan terima kasih kami tujukan pada sdr. Aan Dianto yang telah membantu dalam pembuatan peta lokasi sampling. Tak lupa penulis 
ucapkan terima kasih pada pemerintah yang telah mendanai kegiatan penelitian ini melalui skema program Prioritas Nasional: Pengelolaan Danau Maninjau Berbasis Daya Dukung Ekosistem Guna Mendukung Sektor Perikanan dan Pariwisata di Danau Maninjau tahun 2019.

\section{Daftar Pustaka}

APHA. (2005). Standard methods for the examination of water and waste water. in: A.D Eaton, L.S Clesceri, M.A.H. Franson, E.W. Rice, A.E Greenberg (eds): American public health association. American water work association and water environmental federation Inc. Volume 5. New York. 1220 pp.

Anonymous. (2004). pH Requirements of freshwater aquatic life, Robertson-Bryan Inc. $13 \mathrm{pp}$.

Arlindia, I., \& Afdal. (2015). Analisis pencemaran Danau Maninjau dari nilai TDS dan konduktivitas listrik. Jurnal Fisika Unan,4 (4), 324-331.

Ashton, M.J., Morgan, R.P., \&Stranko, S. (2014). Relations between macroinvertebrates, nutrients, and water quality criteria in wadeable streams of Maryland, USA. Environ. Monit. Assess.186, 1167-1182.

Barbour, M.T., Gerritsen, J., Snyder, B.D., \&Stribling, J.B. (1999). Rapid bioassessment protocols for use in streams and wadeable rivers: periphyton, benthic macroinvertebrates and fish, Second edition, EPA 841-B-99-002. US-EPA. Office of Water Washington D.C.

Barlow-Busch, L., Baulch, H.M.,\&Taylor, W.D. (2006). Phosphate uptake by seston and epilithon in the Grand River, southern Ontario. Aquatic Sciences, 68(2),181-192.

Benetti, C.J., Pérez-Bilbao, A., \&Garrido, J. (2012). Macroinvertebrates as Indicators of Water Quality in Running Waters: 10 Years of Research in Rivers with Different Degrees of Anthropogenic Impacts. In: Voudouris (eds). Ecological Water Quality-Water Treatment and Reuse, InTech. China. 95-122.

Bhandari, B., Tachamo Shah, R.D., \&Sharma, S. (2018). Status, distribution and habitat specificity of benthic macroinvertebrates: A case Study in five tributaries of Buddhiganga River in Western Nepal. Journal of Institute of Science and Technology ,23,69-75.
Besacier-Monbertrand, A.L., Paillexa, A., \&Castella, B.E. (2014). Short-term impacts of lateral hydrological connectivity restoration on aquatic macroinvertebrates. River Res. Applic. 30, 557-570.

Brabec, K., Zahradkova, S., Nemejcova, D., Paril, J., Kokeš, P., \&Jarkovsk, J. (2004). Assessment of organic pollution effect considering differences between lotic and lentic stream habitats. Hydrobiologia, 516, 331-346.

Cesar, D.A.S.,\& Henry, R. (2017). Is similar the distribution of Chironomidae (Diptera) and Oligochaeta (Annelida, Clitellata) in a river and a lateral fluvial area? Acta Limnologica Brasiliensia 29 http://doi.org/10.1590/S2179-975x 1217

Chessman, B. (2003). Signal 2 - A Scoring System for macroinvertebrate (water bug) in Australian River, Monitoring river health initiative technical report no 31, Commonwealth in Australia. Canberra. 32pp.

Cobo, R.J., Everaert, G., Iñiguez-Vela, X., Córdova-Vela, G., Díaz-Granda, C., Cisneros, F., Nopens, I., \&Goethals, P.L.M. (2017). A Methodology to model environmental preferences of ept taxa in the Machangara River Basin (Ecuador). Water, 195(9), 1-31. https:// doi.org/10.3390/w9030195

Czekanowski, J. (1909). Zur differential-diagnose der neander-talgruppe, korrespbl. Dt. Ges. Anthrop. 40,44-47.

Decamps, H., Naiman, R.J., \&McClain, M.E. (2009). Riparian zones, in: Likens G.E. (eds). Encyclopedia of Inland Waters, Elsevier, USA. 396-403.

Ekawati, I. (2005). Mineralisasi nitrogen pada pengomposan jerami. Jurnal AGRITEK.5(2): 1-3.

Frame, H., \& Reiter, M.S. (2013). Enhanced efficiency fertilizer materials: Nitrogen stabilizer. Petersburg: Virginia Polytechnic Institute and State University.

Gee, G.W.,\& Bauder, J.W. (1986). Particle size analysis, in: Klute A. (eds). Methods of Soil Analysis (Part 1). Physical and mineralogical methods. second edition. American Society of Agronomy, Agronomy Monograph 9 (1), Madison, Wisconsin, 1188pp.

Hamid, S.A.,\& Rawi, C.S. (2017). Application of aquatic insects (Ephemeroptera, Plecoptera and Trichoptera) in water quality 
assessment of Malaysian Headwater. Tropical Life Sciences Research,28(2), 143-162.

Hamid, S.A.,\& Rawi, C.S. (2011). Influence of substrate embeddedness and canopy cover on the distribution of Ephemeroptera, Plecoptera and Trichoptera (EPT) in tropical rivers, Aquatic Insects: International Journal of Freshwater Entomology, 33(4), 281-292.

Hanafi, S., \&Purnama, J. (2012). Konsentrasi nutrien di saluran pembuangan Kota Makassar: Sebuah survei awal. Jurnal Sainsmat, 1(1), 68-78.

Hines, S.L.,\& Hershey, A.E. (2011). Do channel restoration structures promote ammonium uptake and improve macroinvertebratebased water quality classification in urban streams? InlandWaters, 1, 133-145.

Irwan, F.,\& Afdal. (2016). Analisis hubungan konduktivitas listrik dengan total dissolved solid (tds) dan temperatur pada beberapa jenis air. Jurnal Fisika Unand, 5(1): 85-93.

Jones, J.I., Murphy, J.F., Collins, A.L., Sear, D.A., Naden, P.S., \&Armitage, P.D. (2012). The impact of fime sediment on macroinvertebrates. River Research and Application, 28, 1055-1071.

Jun, Y.C., Kim, N., Kwon, S., Han, S., Hwang, I., Park, J., Won, D., Byun, M., Kong, H., Lee, J.,\& Hwang, S. (2011). Effects of land use on benthic macroinvertebrate communities: Comparison of two mountain streams in Korea. Annales de Limnologie International Journal of Limnology,47, 3549.

Juwitanti, E., Ain, C., \&Soedarsono, P. (2013). Kandungan nitrat dan fosfat air pada proses pembusukan eceng gondok (Eichhornia Sp.), Diponegoro Journal of Maquares, 2, 46-52.

Kasno, A. (2009). Jenis dan sifat pupuk anorganik. Balai Penelitian Tanah, Bogor.

Kemp, P., Sear, D., Collins, A., Naden, P.,\&Jones, I. (2011). The Impacts of fine sediment on riverine fish. Hydrological Processes, 25, 1800-1821.

Kovach, W.L., (2010). MVSP - A MultiVariate Statistical Package for Windows, ver. 3.2. Kovach Computing Services. Pentraeth. Wales. U.K.

Kuliberg, A. (1992). Benthic macroinvertebrate community structure in 20 streams of varying $\mathrm{pH}$ and humic content. Environmental Pollution,78, 103-106.
Maneechan, W., \& Prommi, T.O. (2015). Diversity and distribution of aquatic insects in streams of the Mae Klong watershed, Western Thailand. Psyche A Journal of Entomology, 2015(2), 1-7, http://doi.org/10.1155/2015/912451

Merritt, R.W.,\& Cummins, K.W. (2019). An introduction of the aquatic insects of North America, 5" Edition. Kendall Hunt Publishing Company. Dubuque. Iowa. 1498 pp.

Miller, S.W., Budy, P., \& Schmidt, J.C. (2010). Quantifying macroinvertebrate responses to in-stream habitat restoration: applications of meta-analysis to river restoration. Restoration Ecology, 18(1), 8-19.

Molokwu, N.D., Pedro, G., Bradshaw, T., Blake, A., Henessey, C., \& Merten, E. (2014). Effects of substrate on the benthic macroinvertebrate community: an experimental approach. Ecological Engineering, 73, 109-114.

National Research Council (NRC). 2002. Riparian Areas: Functions and Strategies for Management. Washington, DC: The National Academies Press. https://doi.org/ 10.17226/10327

Quinn, J.M., Davies-Colley, R.J., Hickey, C.W., Vickers, M.L., \&Ryan, P.A. (1992) . Effects of clay discharges on streams. 2. Benthic invertebrates. Hydrobiologia, 248, 235-247.

Reice, S.R., \&Wohlenberg, M., (1993). Monitoring freshwater benthic macroinvertebrates and benthic processes: measure for asssessment of ecosystem health, in D. Rosenberg \& V.H. Resh (Eds): Freshwater Biomonitoring and Benthic Macroinvertebrates, Chapman \& Hall. New York. 287-305 hal.

Ruzickova, S., Weissova, V., Uher, B., \&Helesic, J. (2017). Macroinvertebrate herbivores and epilithon algae community of a stream affected by mineralized heated mining water inflow. Ann. Limnol- Int. J. Lim., 53(2017), 189-201.

Putri, F.D.M., Wisyastuti, E., \&Christiani. (2014). Hubungan perbandingan total nitrogen dan total fosfor dengan kelimpahan chrysophyta di perairan Waduk Panglima Besar Soedirman, Banjarnegara.Scripta Biologica, 1(1), 196-101.

Saragih, D., Hamim, H., \&Nurmauli, N. (2013). Pengaruh dosis dan waktu aplikasi pupuk urea dalam meningkatkan pertumbuhan dan 
hasil jagung pioneer 27. J. Agrotek Tropik, $1(1), 50-54$.

Spänhoff, B.,\& Arle, J. (2007). Setting attainable goals of stream habitat restoration from a macroinvertebrate view.Restoration Ecology, 15, 317-320.

StatSoft.Inc. (2011). STATISTICA (data analysis software system), version 10. www.statsoft. com.

Stoyanova, T., Vidinova, Y., \&Tyufekchieva, V. (2014). Ephemeroptera, Plecoptera and Trichoptera as indicators for ecological quality of the Luda Reka River, Southwest Bulgaria. Acta Zoologica Bulgarica, 66(2), 255-260.

Sultana, J., Recknagel, F., Tibby, J., \&Maxwell, S. (2019). Comparison of water quality thresholds for macroinvertebrates in two Mediterranean catchments quantified by the inferential techniques TITAN and HEA. Ecological Indicators, 101, 867-877.

Thorp, J.H., \& Covich, A.P. (1991). Ecology and classification of North American freshwater invertebrates. Academic Press. Inc. New York.

US-EPA. (2017), Water Quality 101. Retrieved from https://ace-project.org/water-quality$101 \%$.

Yanti, E.V. (2017). Dinamika musiman kualitas air di daerah Sungai Kahayan Kalimantan Tengah. Ziraa'ah, 42(2), 107-118.

Yustiawati, Syawal, M., \&Aisyah, S., (2019). Pengukuran kondisi fisika dan kimia Sungai Ranggeh dalam rangka pengelolaan perikanan di Danau Maninjau. Prosiding Pertemuan Ilmu Lingkungan Nasional Universitas Padjadjaran. 


\section{Sudarso et al.}

\section{Lampiran}

Lampiran 1.Komposisi komunitas makrozoobentos di Sungai Ranggeh(keterangan $1=$ ada, $0=$ tidak ada). Appendix 1. Composition of macrozoobenthic communities in the Ranggeh River. (annotation $1=$ present, 0 $=$ absent)

\begin{tabular}{|c|c|c|c|c|c|c|c|c|}
\hline \multirow{3}{*}{ Taksa } & \multirow{3}{*}{ Ordo } & \multicolumn{7}{|c|}{ Sampling Sites } \\
\hline & & SR & SR & SR & SR & SR & SR & SR \\
\hline & & & & & 4.1 & 4.2 & & \\
\hline Neoperla sp. & Plecoptera & 1 & 1 & 0 & 0 & 1 & 0 & 0 \\
\hline Indonemoura & Plecoptera & 1 & 0 & 0 & 0 & 0 & 0 & 0 \\
\hline Amphinemura & Plecoptera & 1 & 1 & 0 & 0 & 0 & 0 & 0 \\
\hline Ceratopsyche cf ventura & Trichoptera & 1 & 1 & 1 & 0 & 1 & 1 & 1 \\
\hline Hydropsyche sp. & Trichoptera & 1 & 1 & 0 & 0 & 0 & 0 & 0 \\
\hline Cheumatopsyche & Trichoptera & 1 & 1 & 0 & 0 & 1 & 0 & 1 \\
\hline Genus 1 (undescribed) & Trichoptera & 1 & 0 & 0 & 0 & 0 & 0 & 0 \\
\hline Hydromanicus & Trichoptera & 0 & 1 & 0 & 0 & 0 & 0 & 0 \\
\hline Macrostemum & Trichoptera & 0 & 0 & 0 & 0 & 1 & 0 & 1 \\
\hline Diplectrona & Trichoptera & 0 & 0 & 0 & 0 & 0 & 0 & 1 \\
\hline Agapetus & Trichoptera & 1 & 1 & 0 & 0 & 1 & 0 & 0 \\
\hline Tinodes & Trichoptera & 1 & 0 & 0 & 0 & 0 & 0 & 0 \\
\hline Lepidostoma cf hirtum & Trichoptera & 1 & 1 & 0 & 0 & 0 & 0 & 0 \\
\hline Brachycentrus & Trichoptera & 0 & 1 & 0 & 0 & 0 & 0 & 0 \\
\hline Wormaldia sp. & Trichoptera & 0 & 0 & 0 & 0 & 0 & 0 & 1 \\
\hline Hydroptila & Trichoptera & 0 & 0 & 0 & 0 & 1 & 0 & 0 \\
\hline Erotesis & Trichoptera & 0 & 0 & 0 & 0 & 1 & 0 & 1 \\
\hline Oecetis & Trichoptera & 0 & 0 & 0 & 0 & 0 & 0 & 1 \\
\hline cf. Notoperata & Trichoptera & 0 & 0 & 0 & 0 & 0 & 0 & 1 \\
\hline Eoophyla & Lepidoptera & 1 & 1 & 0 & 0 & 1 & 0 & 1 \\
\hline Eoophyla sp 1 & Lepidoptera & 0 & 0 & 0 & 0 & 1 & 0 & 1 \\
\hline Hydrobasileus sp. & Odonata & 1 & 0 & 0 & 0 & 0 & 0 & 0 \\
\hline cf Zyxomma & Odonata & 0 & 1 & 0 & 0 & 0 & 0 & 0 \\
\hline Anax cf geogius & Odonata & 1 & 0 & 0 & 0 & 0 & 0 & 0 \\
\hline Macromia & Odonata & 1 & 0 & 0 & 0 & 0 & 0 & 0 \\
\hline cf. Erpetogomphus & Odonata & 0 & 0 & 1 & 0 & 0 & 0 & 0 \\
\hline Platybaetis gagadjuensis & Ephemeroptera & 1 & 1 & 0 & 0 & 1 & 1 & 1 \\
\hline Baetis sp. & Ephemeroptera & 1 & 1 & 0 & 1 & 1 & 1 & 1 \\
\hline Tricorythodes & Ephemeroptera & 1 & 0 & 0 & 0 & 0 & 0 & 0 \\
\hline Caenis & Ephemeroptera & 0 & 1 & 0 & 0 & 1 & 0 & 1 \\
\hline Simsonia longipes & Coleoptera & 1 & 1 & 0 & 0 & 0 & 0 & 0 \\
\hline Simsonia leai & Coleoptera & 0 & 0 & 0 & 0 & 1 & 0 & 1 \\
\hline Stenelmis & Coleoptera & 1 & 0 & 0 & 0 & 1 & 0 & 0 \\
\hline cf. Ancyronyx & Coleoptera & 0 & 0 & 0 & 0 & 1 & 0 & 0 \\
\hline Microcylloepus & Coleoptera & 0 & 1 & 0 & 0 & 1 & 0 & 1 \\
\hline Zaitsevia & Coleoptera & 0 & 1 & 0 & 0 & 1 & 0 & 0 \\
\hline Elmomorphus sp. & Coleoptera & 1 & 1 & 0 & 0 & 1 & 0 & 0 \\
\hline Cercyon sp. & Coleoptera & 1 & 0 & 0 & 0 & 0 & 0 & 0 \\
\hline Berosus sp. & Coleoptera & 1 & 0 & 0 & 0 & 0 & 1 & 0 \\
\hline
\end{tabular}


Oseanologi dan Limnologi di Indonesia 20205(2): 105-119

\begin{tabular}{|c|c|c|c|c|c|c|c|c|}
\hline Tropisternus & Coleoptera & 0 & 0 & 0 & 0 & 1 & 0 & 0 \\
\hline Laccobius & Coleoptera & 0 & 0 & 0 & 0 & 0 & 0 & 1 \\
\hline Helophorus sp. & Coleoptera & 1 & 0 & 0 & 0 & 0 & 0 & 0 \\
\hline Gyretes sp. & Coleoptera & 0 & 0 & 0 & 0 & 1 & 0 & 0 \\
\hline Prosimulium & Diptera & 1 & 1 & 0 & 0 & 0 & 0 & 0 \\
\hline Greniera & Diptera & 0 & 1 & 0 & 1 & 0 & 1 & 0 \\
\hline Simulium & Diptera & 0 & 0 & 0 & 0 & 1 & 1 & 1 \\
\hline Monopelopia & Diptera & 1 & 1 & 0 & 1 & 1 & 1 & 1 \\
\hline Tanypodinae 1 & Diptera & 0 & 0 & 0 & 1 & 0 & 1 & 0 \\
\hline Procladius & Diptera & 0 & 0 & 0 & 1 & 0 & 0 & 0 \\
\hline Polypedilum & Diptera & 1 & 1 & 0 & 1 & 1 & 1 & 1 \\
\hline Cryptochironomus & Diptera & 0 & 0 & 0 & 1 & 1 & 1 & 1 \\
\hline Tanytarsus & Diptera & 0 & 0 & 0 & 1 & 1 & 1 & 1 \\
\hline Rheotanytarsus & Diptera & 0 & 0 & 0 & 1 & 0 & 1 & 0 \\
\hline Eukeifferiella & Diptera & 0 & 0 & 0 & 1 & 0 & 1 & 0 \\
\hline Orthocladius & Diptera & 0 & 0 & 0 & 1 & 1 & 1 & 1 \\
\hline Nanocladius & Diptera & 0 & 0 & 0 & 1 & 1 & 1 & 1 \\
\hline Parakieferiella & Diptera & 0 & 0 & 0 & 1 & 1 & 1 & 1 \\
\hline Orthocladinae 1 & Diptera & 0 & 0 & 0 & 1 & 0 & 1 & 1 \\
\hline Orthocladinae 2 & Diptera & 0 & 0 & 0 & 1 & 0 & 1 & 1 \\
\hline Rheocricotopus & Diptera & 0 & 0 & 0 & 0 & 0 & 1 & 1 \\
\hline Orthocladinae 3 & Diptera & 0 & 1 & 0 & 0 & 0 & 1 & 1 \\
\hline Chironomus & Diptera & 0 & 0 & 0 & 1 & 1 & 1 & 1 \\
\hline Tanytarsini 1 & Diptera & 0 & 0 & 0 & 1 & 1 & 1 & 1 \\
\hline Dicranota & Diptera & 0 & 0 & 0 & 0 & 1 & 0 & 0 \\
\hline Eloeophila Rondani,1856 & Diptera & 0 & 0 & 0 & 0 & 1 & 0 & 0 \\
\hline Limonidae sp 1 & Diptera & 0 & 0 & 0 & 0 & 0 & 0 & 1 \\
\hline Psychoda & Diptera & 0 & 0 & 0 & 0 & 0 & 0 & 1 \\
\hline Megadrile & Oligochaeta & 0 & 0 & 0 & 1 & 0 & 0 & 0 \\
\hline Pristina synclites & Oligochaeta & 0 & 0 & 0 & 1 & 0 & 1 & 0 \\
\hline Pristina menoni & Oligochaeta & 0 & 0 & 0 & 1 & 0 & 0 & 0 \\
\hline Dero (dero) digitata & Oligochaeta & 0 & 0 & 0 & 1 & 0 & 1 & 0 \\
\hline $\begin{array}{l}\text { Dero(Aulophorus) } \\
\text { flabelliger }\end{array}$ & Oligochaeta & 0 & 0 & 0 & 1 & 0 & 1 & 0 \\
\hline Allonais inequalis & Oligochaeta & 0 & 0 & 0 & 1 & 0 & 1 & 0 \\
\hline Nais communis & Oligochaeta & 0 & 0 & 0 & 1 & 0 & 0 & 0 \\
\hline cf. Placobdella & Hirudinida & 0 & 0 & 0 & 0 & 0 & 1 & 0 \\
\hline Erpobdellidae 1 & Hirudinida & 0 & 0 & 0 & 0 & 1 & 0 & 0 \\
\hline Micronecta & Hemiptera & 0 & 0 & 0 & 1 & 0 & 1 & 0 \\
\hline Ragovelia & Hemiptera & 0 & 0 & 0 & 0 & 1 & 0 & 1 \\
\hline Pelocoris femoratus & Hemiptera & 0 & 0 & 0 & 0 & 0 & 0 & 1 \\
\hline Physa sp. & Gastropoda & 0 & 0 & 0 & 1 & 0 & 0 & 0 \\
\hline Lymnaea & Gastropoda & 0 & 0 & 1 & 0 & 0 & 1 & 0 \\
\hline Gyraulus cf. laevis & Gastropoda & 0 & 0 & 0 & 0 & 0 & 0 & 1 \\
\hline
\end{tabular}

